\title{
PEMEROLEHAN TINDAK TUTUR BAHASA INDONESIA ANAK USIA 4 TAHUN
}

\author{
Qoni'atul Habibah, Arju Mutiah, Ahmad Syukron \\ Universitas Jember \\ qoniatul72@gmail.com
}

ABSTRAK

ABSTRACT

PENDAHULUAN

Bahasa diperoleh dan dipelajari manusia sejak bayi dalam situasi yang alamiah melalui lingkungannya. Bayi memperoleh sebuah bahasa karena didukung oleh kemampuan otaknya dalam memahami 
sebuah bahasa. Manusia lahir mempunyai potensi berbahasa, yaitu berupa alat yang disebut Language Acquisition Device (LAD) yang dianugerahkan oleh Tuhan. Chomsky (dalam Chaer, 2015:169) mengatakan bahwa terdapat alat khusus yang dimiliki setiap anakanak sejak lahir agar mampu untuk berbahasa. Alat tersebut dinamakan LAD atau Piranti Pemerolehan Bahasa (PPB). LAD berfungsi untuk memungkinkan seorang anak memperoleh bahasa ibunya. Dalam proses pemerolehan bahasa, LAD ini menerima ucapan-ucapan dan data-data lain yang berkaitan melalui panca indra sebagai masukan dan membentuk rumus-rumus linguistik berdasarkan masukan itu yang kemudian diubah sebagai output (keluaran).

Anak usia 4 tahun memperoleh bahasa pertamanya melalui lingkungan keluarga, terutama ibu yang mengajarkan bahasa melalui ujaran ataupun tindak tutur. Dardjowidjojo (2000:275) menjelaskan bahwa anak usia dini (0-6 tahun) menggunakan bahasa yang diperolehnya melalui interaksi dengan orang lain, baik dengan anak sebaya, anak-anak yang lebih muda atau dengan orang dewasa di sekitarnya. Jadi, anak mampu menyampaikan maksud yang ingin disampaikan kepada orang-orang di sekitarnya melalui bahasa yang digunakan dan diperolehnya.

Anak pada usia 4 tahun memperoleh bahasa dari yang sederhana hingga kompleks dimulai dari pemerolehan bunyi hingga pada tataran pragmatik. Tindak tutur merupakan salah satu yang diperoleh anak usia 4 tahun pada tataran pragmatik, yaitu tindak tutur deklaratif, tindak tutur imperatif (perintah), dan tindak tutur interogatif (tanya) (Candrasari, 2014).

Pemerolehan bahasa adalah proses bertahap yang berlangsung di dalam otak seorang anak ketika dia memperoleh bahasa pertamanya atau bahasa ibunya (Chaer, 2015:167). Terdapat dua proses yang terjadi ketika anak usia dini sedang memperoleh bahasa pertamanya, yaitu proses kompetensi dan proses performansi. Proses kompetensi adalah proses pemahaman tata bahasa yang berlangsung secara tidak disadari oleh anak. Proses kompetensi akan sangat berpengaruh terhadap proses berikutnya, yaitu performansi yang terdiri atas dua tahapan. Pada tahap pertama, yaitu tahap pemahaman melibatkan kemampuan mempersepsi kalimat-kalimat yang didengar oleh anak, sedangkan tahap produksi melibatkan kemampuan anak untuk menghasilkan kalimat-kalimat sendiri.

Proses kompetensi pada anak usia 4 tahun terjadi ketika anak mendengar rangsangan bahasa berupa tuturan-tuturan dari orang dewasa di sekitarnya. Secara tidak disadari, proses pemahaman terhadap tuturan-tuturan tersebut terjadi dalam otak anak. Setelah anak memahami tuturan tersebut, anak akan mempersepsi tuturan yang didengar, kemudian anak memproduksi tuturan-tuturan yang telah dipahaminya dengan cara meniru tuturan orang dewasa. Tuturan yang diproduksi oleh anak menjadi kemampuan tindak tutur anak yang akan dikuasainya dan digunakan pada situasi-situasi tertentu. 
Dalam kajian pragmatik, menurut Austin (1995), ketika seseorang berbicara, ia tidak hanya mengucapkan sebuah ujaran saja, tetapi ia juga melakukan tindakan dengan ujarannya tersebut. Pandangan ini disebut dengan Speech Act (tindak tutur/tindak ujar) yang terdiri atas lokusi, ilokusi, dan perlokusi. Dalam tindak ilokusi, seseorang berujar atau mengeluarkan ujaran (speech) karena memiliki maksud-maksud tertentu yang akan berdampak pada lawan tuturnya. Dalam hal ini, anak usia 4 tahun bertindak ilokusi dengan mitra tutur untuk menyampaikan maksud saat berkomunikasi dengan orang lain melalui tuturannya. Misalnya, saat anak meminta sesuatu kepada ibunya. Kemudian, anak usia 4-6 tahun mulai menggunakan bahasa yang lebih halus dan menyatakan apa keinginan mereka menggunakan cara atau strategi tindak tutur. Menurut Bates (dalam Asih, 2017), anak usia 0-4 tahun telah mampu melakukan ujaran seperti direct question (pertanyaan langsung) dan imperatives (ujaran perintah).

Penelitian ini dirancang sebagai studi kasus. Studi kasus digunakan dalam penelitian ini karena data yang ditemukan merupakan data yang diambil dari sebuah kasus pada anak bernama Karin. Karin (4 tahun) dipilih sebagai subjek kajian dalam penelitian ini karena Karin sangat komunikatif dengan keluarga dan orang-orang di sekitarnya sehingga banyak variasi tindak tutur yang diproduksinya. Selain itu, diindikasikan pula adanya penggunaan jenis-jenis tindak tutur dan strategi tindak tutur yang diperoleh Karin. Anak usia 4 tahun mampu meramu tuturan-tuturan yang akan digunakan untuk menyampaikan maksud tertentu. Selain itu, anak telah memulai bertindak tutur secara pragmatik dengan cara memilih bentuk tindak tutur untuk menyampaikan maksud tertentu, seperti mengungkapkan tindak tutur memerintah, meminta, meminta maaf, dan tindak tutur lainnya.

Pemahaman anak tentang penggunaan tindak tutur pada situasisituasi tertentu didapat dari lingkungan sekitar saat mereka menangkap dan menyerap berbagai rangsangan bahasa. Rangsangan tersebut dapat diperoleh anak melalui panca indra atau kebiasaankebiasaan yang sering dilakukan oleh anak. Namun, hal tersebut bukanlah faktor utama anak dalam memeroleh bahasa. Faktor pemerolehan bahasa juga dipengaruhi oleh aspek kognitif anak. Dengan bantuan LAD sebagai perangkat pemerolehan bahasa, anak mampu mengolah bahasa yang diterimanya, kemudian diproduksi kembali oleh anak melalui tindak tutur (Parera, 1987:37).

Berdasarkan uraian di atas, dapat dikatakan bahwa aktivitas berkomunikasi anak usia 4 tahun terhadap mitra tutur menjadi topik yang menarik untuk dikaji lebih mendalam. Hal ini didasarkan pada kenyataan fenomena kebahasaan terutama pemerolehan tindak tutur yang dimiliki anak usia 4 tahun sedang mengalami perkembangan. Menurut Yusuf (2004), anak usia 4 tahun memiliki kemampuan berkomunikasi yang baik dengan mitra tutur, misalnya meminta, memerintah, dan menjawab pertanyaan-pertanyaan mitra tutur. Tuturan tersebut digunakan oleh anak usia 4 tahun untuk mengembangkan kemampuan penyesuaian sosial (social adjustment). Berdasarkan alasan yang dipaparkan di atas, maka dilakukan 
penelitian pemerolehan tindak tutur bahasa Indonesia anak usia 4 tahun.

Rancangan yang digunakan dalam penelitian ini adalah penelitian kualitatif. Bogdan dan Taylor (dalam Moleong, 2009:4) menjelaskan bahwa penelitian kualitatif merupakan penelitian yang menghasilkan data deskriptif berupa kata-kata tulisan atau lisan dari orang-orang yang diamati melalui perilaku. Pada penelitian ini, digunakan penelitian kualitatif dengan metode studi kasus. Menurut Sukmadinata (2012:77), studi kasus (case study) merupakan metode untuk menghimpun dan menganalisis data berkenaan sesuatu kasus. Jenis penelitian yang digunakan dalam penelitian ini adalah pemerolehan deskriptif-psikopragmatik karena penelitian ini mendeskripsikan jenis-jenis tindak tutur dan strategi tindak tutur yang diperoleh anak usia 4 tahun, serta peran lingkungan terhadap pemerolehan tindak tutur anak tersebut.

Data dalam penelitian ini berupa segmen tutur anak usia 4 tahun dalam percakapan sehari-hari yang diindikasikan sebagai tindak tutur tertentu beserta konteksnya. Selain itu, data berupa hasil wawancara kepada orang tua anak dan orang-orang di lingkungannya yang mengindikasikan peran lingkungan terhadap pemerolehan tindak tutur anak tersebut. Sumber data dalam penelitian ini adalah tuturan dalam percakapan yang melibatkan Karin dan lingkungannya. Dalam hal ini, tuturan anak bernama Karunia Putri Anindita (Karin) usia 4 tahun sebagai objek penelitian. Karin lahir di Situbondo, 9 September 2015. Tuturan tersebut terdapat dalam peristiwa tutur saat subjek penelitian sedang bermain dengan teman-temannya, saat menonton televisi atau youtube, dan ketika bercakap-cakap bersama orang-orang di sekitarnya. Karin memiliki latar belakang bahasa yang beragam, yaitu bahasa Indonesia, bahasa Jawa, dan bahasa Madura sehingga diindikasikan terdapat tuturan-tuturan bahasa Indonesia yang bercampur dengan bahasa Jawa atau pun bahasa Madura yang dituturkan oleh Karin.

Teknik pengumpulan data yang digunakan adalah teknik observasi dan wawancara. Penelitian ini menggunakan teknik observasi atau pengamatan dengan terjun langsung ke lapangan untuk mengamati secara langsung subjek yang diteliti. Teknik rekam dan teknik catat lapang dibutuhkan sebagai pendukung dalam teknik observasi. Dengan menggunakan teknik rekam, peneliti merekam semua ujaran subjek (anak usia 4 tahun) dengan alat rekam (telepon genggam) yang telah disediakan. Teknik catat lapang digunakan untuk mencatat segala peristiwa, tempat, dan waktu perujaran ketika observasi dilakukan. Teknik wawancara dilakukan terhadap orang tua objek penelitian (Karin) dan orang-orang yang terlibat dalam percakapan dengan subjek penelitian. Hal ini dilakukan untuk mendapatkan data mengenai peran lingkungan terhadap pemerolehan tindak tutur anak usia 4 tahun.

Teknik analisis data yang digunakan dalam penelitian ini adalah teknik analisis data model interaktif yang dikemukakan oleh Miles dan Huberman. Teknik analisis data yang digunakan pada penelitian ini 
terdiri atas tiga tahap, yaitu reduksi data, penyajian data, dan penarikan kesimpulan. Terdapat dua instrumen yang digunakan dalam penelitian ini, yaitu instrumen utama dan instrumen pendukung. Instrumen utama dalam penelitian ini, yaitu peneliti, sedangkan instrumen pendukung dalam penelitian ini adalah alat bantu berupa alat rekam, alat tulis, dan tabel analisis data, serta teori-teori yang mendukung penelitian ini.

PEMBAHASAN
Hasil penelitian menunjukan bahwa pemerolehan tindak tutur bahasa Indonesia anak usia 4 tahun mulai beragam. Berdasarkan penelitian yang telah dilakukan, ditemukan lima jenis tindak tutur yang diperoleh anak usia 4 tahun mencakup: (1) tindak tutur asertif, (2) tindak tutur direktif, (3) tindak tutur komisif, (4) tindak tutur ekspresif, dan (5) tindak tutur deklaratif; Dua strategi tindak tutur bahasa Indonesia yang diperoleh anak usia 4 tahun mencakup: (1) strategi tindak tutur langsung harfiah, dan (2) strategi tindak tutur tak langsung harfiah. Tiga peran lingkungan terhadap pemerolehan tindak tutur bahasa Indonesia anak usia 4 tahun, yaitu (1) orang tua dan keluarga, (2) teman dan masyarakat, dan (3) objek-objek di sekitar anak.

\section{Pemerolehan Jenis Tindak Tutur Bahasa Indonesia Anak Usia 4 Tahun}

Manusia dalam menyampaikan maksud tuturannya menggunakan jenis tindak tutur yang disesuaikan dengam kebutuhan. Berdasarkan data yang diperoleh, jenis tindak tutur yang diperoleh anak usia 4 tahun mencakup: (1) tindak tutur asertif, (2) tindak tutur direktif, (3) tindak tutur komisif, (4) tindak tutur ekspresif, dan (5) tindak tutur deklaratif.

\section{Tindak Tutur Asertif}

Tindak tutur asertif merupakan tindak tutur yang mengikat penuturnya atas kebenaran informasi. Jenis-jenis tindak tutur asertif, yaitu menyatakan, mengusulkan, mengeluh, melaporkan, dan menunjukkan. Berdasarkan penelitian yang telah dilakukan, ditemukan tiga jenis tindak tutur asertif yang diperoleh anak usia 4 tahun, yaitu (1) menyatakan, (2) melaporkan, dan (3) menunjukkan.

\section{a. Tindak Tutur Asertif Menyatakan}

Tindak asertif menyatakan adalah tuturan yang memiliki maksud untuk menerangkan, menjelaskan, dan mengemukakan pikiran atau pendapat pribadi. Tindak tutur asertif menyatakan yang diperoleh anak usia 4 tahun tercermin pada data dan analisis berikut ini.

Segmen Tutur Data (2)

\section{Karin : "Bunda, aku pinter, Bunda. Banyak,} Bunda." (sambil menunjukkan gamebot air kepada Bunda)

Bunda: (melihat gamebot air yang ditunjukkan oleh Karin)

Bunda: "Ayo kakak mik cucu nanti bawa sini." 
Konteks:

Tuturan terjadi di ruang keluarga ketika Karin bermain gamebot air. Kemudian, Karin berhasil memasukkan semua ring dalam gamebot. Lalu, penutur mendekati mitra tutur (Bunda) sambil menunjukkan hasil permainannya yang telah dicapai.

(TTAsMyt:1)

Data (1) Bunda, aku pinter, Bunda. Banyak, Bunda merupakan tindak tutur asertif menyatakan. Pada tuturan tersebut, Karin bermaksud menyatakan bahwa dirinya pintar dalam bermain gamebot kepada mitra tutur (Bunda). Maksud tersebut diketahui dari tuturan Bunda, aku pinter, Bunda sambil menunjukkan hasil permainannya kepada Bunda dan mendekati mitra tutur. Tuturan tersebut menandakan bahwa Karin menyatakan bahwa dirinya pintar karena telah memasukkan banyak ring dalam gamebot. Selain itu, Karin yang mendekati Bunda dan menunjukkan hasil permainannya menjadi penanda bahwa Karin bermaksud agar mitra tutur mengetahui kemahirannya.

\section{b. Tindak Tutur Asertif Melaporkan}

Tindak tutur asertif melaporkan adalah tuturan yang diucapkan oleh penutur dengan maksud memberi tahu suatu informasi yang dianggap penting kepada mitra tutur. Tindak tutur asertif melaporkan yang diperoleh anak usia 4 tahun terdapat dalam data dan analisis berikut ini.

Segmen Tutur Data (3)

Karin : "Liat apa itu? Liat! Ada Fatim?"

Bunda : "Boh dak tau Fatim. Ada di sana."

Karin : "Aku dak ikut joget. Lagi lagi."

Bunda : "Adek lah."

(Sudah gak ada)

Karin : "Lagi koh, Bunda."

Bunda : "Ndak ada dah. Itu ibunya Nadia. Coba ke sana."

Karin : "Fatim dak joget di Mbak Dia. Dak seneng."

Tante : "Sapa gak seneng?"

Karin : "Fatim"

Tante : "Fatim?"

Karin : "Iya ndak mau joget. Itu Mbak Dia joget. Fatim dak ikut joget."

Konteks:

Tuturan terjadi di ruang keluarga ketika Karin bersama bundanya menonton video teman-temannya yang berjoget di HP bundanya. Karin menarik HP bundanya karena ingin menonton video tersebut. 
Data (3) Fatim dak joget di Mbak Dia. Dak seneng merupakan tindak tutur asertif melaporkan. Pada tuturan tersebut, Karin bermaksud melaporkan kepada tantenya bahwa temannya yang bernama Fatim tidak suka berjoget. Hal tersebut ditandai dengan tuturan (Fatim) Dak seneng yang menandakan bahwa Karin melaporkan apa yang diketahuinya. Karin melaporkan hal tersebut kepada mitra tutur setelah menonton video. Karin mengaitkan apa yang diketahuinya, yaitu tentang Fatim yang tidak suka berjoget dengan isi video yang telah ditontonnya. Tuturan yang terjadi ketika Karin menonton video teman-temannya yang sedang berjoget membuat Karin ingin melaporkan sesuatu yang berkaitan dengan isi video yang telah ditontonnya.

\section{c. Tindak Tutur Asertif Menunjukkan}

Menurut Tarigan (1990:47), tindak tutur asertif menunjukkan adalah tindak tutur yang dituturkan oleh penutur untuk menerangkan sesuatu dengan memperlihatkan suatu objek. Tindak tutur ini ditandai dengan penggunaan kata tunjuk (ini, itu, berikut, begini, begitu, di sini, di situ) untuk menunjukkan objek yang dimaksud, ada hal yang dipertunjukkan (gerakan nonverbal). Wujud tindak tutur asertif menunjukkan pada penelitian ini ditemukan sebagai berikut.

Segmen Tutur Data (5)

Karin : “Tuh Te. Hantu, Te. Tuh, Te! Hantu. Huu takut. Takut. Itu lho hantu koh! Aaaw!" (sambil ketakutan dan berteriak)

Karin : "Tuh kan hantu itu kan. Hantu malem, Te!"

Tante : "Bukan hantu itu."

Karin : "Apa?"

Tante : "Kuburan."

Konteks:

Tuturan terjadi di ruang keluarga ketika Karin bersama tantenya menonton televisi pada malam hari tentang makam-makam para pahlawan. Karin mendekap tangannya sambil mendekati mitra tutur (Tante) dan bersembunyi di belakang mitra tutur. Dituturkan dengan nada ketakutan sambil menunjuk-nunjuk televisi.

(TTAsMnj:5)

Data (5) Tuh Te. Hantu, te. Tuh te. Hantu! merupakan tindak tutur asertif menunjukkan. Karin menunjukkan kepada tantenya bahwa di televisi ada kuburan atau makam yang berarti ada hantu juga menurut Karin. Pada tuturan tersebut, Karin bermaksud menunjukkan kepada tantenya bahwa ada hantu di televisi. Maksud tersebut diketahui dari penggunaan kata 'tuh' (itu) sebagai penanda bahwa tuturan tersebut merupakan tindak tutur asertif menunjukkan. Karin menambahkan tindak tutur asertif menunjukkan pada ujaran selanjutnya yang berselang beberapa saat setelah mengujarkan tuturan 
pertama. Tuh kan hantu itu kan merupakan tuturan yang ditambahkan oleh Karin. Pada tuturan tersebut, ditemukan pula penggunaan kata 'tuh' dan 'itu' sebagai penanda tindak tutur asertif menunjukkan.

Berdasarkan data yang ditemukan, pemerolehan tindak tutur asertif yang terjadi pada Karin disebabkan oleh kemauan yang besar dari diri anak untuk bercerita, memberitahukan segala sesuatu yang baru bagi si anak kepada mitra tutur, atau pun memamerkan hal-hal yang membuat anak merasa bangga diri kepada mitra tutur. Hal ini sesuai dengan pendapat Santrock (2007) yang menjelaskan bahwa perkembangan emosi pada masa kanak-kanak awal ditandai dengan munculnya emosi evaluatif yang didasarkan oleh rasa bangga diri. Perasaan ini akan muncul ketika anak merasakan kesenangan setelah sukses melakukan perilaku tertentu. Setiap anak memiliki cara yang berbeda-beda dalam mengekspresikan rasa bangganya. Misalnya, dengan menceritakan suatu hal baru kepada mitra tutur atau memamerkan kehebatannya dalam melakukan sesuatu kepada mitra tutur.

\section{Tindak Tutur Direktif}

Tindak tutur direktif merupakan tindak tutur yang digunakan oleh penutur dengan maksud agar mitra tutur melakukan hal yang diinginkan penutur. Sesuai dengan penelitian yang telah dilakukan, ditemukan tindak tutur yang diperoleh anak usia 4 tahun berwujud direktif ada tiga, yaitu (1) meminta, (2) memerintah atau menyuruh, dan (3) melarang.

\section{a. Tindak Tutur Direktif Meminta}

Tindak tutur direktif meminta adalah suatu tuturan yang diucapkan oleh penutur kepada mitra tutur dengan maksud apa yang diinginkan oleh penutur dipenuhi oleh mitra tutur. Prayitno (2011:46) menyatakan bahwa direktif permintaan adalah suatu tuturan yang bertujuan untuk memohon dan mengharapkan kepada mitra tutur supaya diberi sesuatu atau menjadi sebuah kenyataan sebagaimana yang diminta oleh penutur. Tindak tutur direktif meminta yang diperoleh anak usia 4 tahun tercermin dalam analisis berikut.

Segmen Tutur Data (8)

Karin : "Mara, Bunda mik cucu, Bunda!"

(Ayo Bunda minum susu, Bunda)

Bunda : "Lho iyo iki adik gak gelem. Ayo, Dik. Ayo, Dik."

(Lho iya ini adik gak mau. Ayo, Dik. Ayo, Dik.)

Konteks:

Tuturan terjadi di ruang keluarga ketika Karin baru pulang dari sekolah dan setelah berganti baju. Kebiasaan Karin ketika pulang sekolah adalah minum susu menggunakan botol dot di rumah belakang. Dituturkan nada rendah dan dengan ekspresi wajah memohon. 
Data (8) Mara, Bunda mik cucu, Bunda! merupakan tindak tutur direktif meminta. Karin meminta susu kepada bundanya menggunakan kalimat dengan campuran bahasa Madura. Kata mara pada kalimat Mara Bunda mik cucu, Bunda! memiliki arti 'ayo'. Pada tuturan tersebut, Karin bermaksud agar mitra tutur (Bunda) melakukan suatu tindakan, yaitu membuatkan susu lalu memberikannya kepada Karin. Maksud tersebut diketahui dari tuturan Karin mik cucu Bunda yang dituturkan dengan nada rendah dan memohon kepada mitra tutur agar dibuatkan susu. Selain itu, ditandai pula dengan kebiasaan Karin, yaitu minum susu sepulang sekolah lalu memintanya kepada Bunda.

\section{b. Tindak Tutur Direktif Memerintah atau Menyuruh}

Tindakan menyuruh atau memerintah mengindikasikan bahwa ketika mengucapkan suatu tuturan, penutur menghendaki mitra tutur untuk melakukan perbuatan atau tindakan. Prayitno (2011:51) menyatakan bahwa tindak tutur direktif perintah adalah perkataan yang bermaksud menyuruh mitra tutur melakukan sesuatu. Tindak tutur direktif memerintah ini ada semacam aba-aba, komando, atau aturan dari pihak penutur sebagai orang yang merasa lebih tinggi kedudukannya. Tindak tutur direktif menyuruh atau memerintah yang diperoleh anak usia 4 tahun tercermin dalam analisis berikut.

Segmen Tutur Data (11)

Bunda : "Mik cucu ayo, Le!" (sambil menarik tangan Haidar)

Karin : "Tunggu aku Bunda!"

Konteks:

Tuturan terjadi di ruang keluarga ketika Karin baru tiba di rumah dari sekolahnya. Dituturkan dengan nada tinggi. Karin sedang berganti baju lalu Bunda mengajak Haidar (putranya) minum susu di rumah belakang. Lalu, Karin dengan cepat mengganti bajunya ketika Bunda mengajak Haidar minum susu.

(TTDirMnt:11)

Data (11) Tunggu aku, Bunda! merupakan tindak tutur direktif menyuruh. Hal tersebut tercermin dalam tuturan Karin Tunggu aku Bunda. Pada tuturan tersebut, Karin bermaksud agar mitra tutur (Bunda) jangan beranjak pergi sebelum Karin selesai berganti baju. Maksud tersebut dapat diketahui dari penggunaan kata 'tunggu' yang menjadi penanda bahwa Karin menyuruh bundanya untuk tidak pergi terlebih dahulu. Tuturan tersebut Karin ujarkan karena adanya konteks yang mendukung. Bunda yang mengajak Haidar minum susu di rumah belakang ketika Karin sedang berganti baju membuat Karin menuturkan perintah agar ditunggu dan jangan sampai ditinggal pergi.

c. Tindak Tutur Direktif Melarang

Melarang adalah suatu bentuk tuturan yang mempunyai maksud agar apa yang diucapkan mitra tutur, mitra tutur tidak melakukan 
tindakan oleh karena ujaran penutur. Prayitno (2011:63) menyatakan bahwa tindak tutur direktif larangan merupakan tindak bahasa yang bertujuan supaya mitra tutur tidak boleh sama sekali atau dilarang melakukan sesuatu. Berikut data dan analisis tindak tutur direktif melarang yang diperoleh anak usia 4 tahun.

Segmen Tutur Data (14)

\section{Karin : "Jangan duduk situ, Kung!" \\ Kakung : "Perute sakit." \\ (Perutnya sakit)}

Konteks:

Tuturan terjadi ketika Karin sedang menonton televisi, kemudian melihat kakungnya duduk di atas meja karena perutnya yang sakit apabila duduk di lantai. Karin melarang kakungnya agar tidak duduk di meja. Lalu, Kakung memberi alasan mengapa harus duduk di meja sambil memegang perutnya.

(TTDirMlr:14)

Data (14) Jangan duduk situ, Kung! merupakan tindak tutur direktif melarang. Segmen tutur di atas menjelaskan bahwa penutur melarang mitra tutur agar tidak duduk di meja. Kemudian, mitra tutur memberi alasan bahwa perutnya sedang sakit sehingga harus duduk di atas meja. Tuturan Jangan duduk situ, Kung! diujarkan oleh Karin dengan maksud agar mitra tutur melakukan suatu tindakan, yaitu tidak duduk di atas meja atau pindah tempat duduk. Hal tersebut ditandai dengan penggunaan kata 'jangan' yang memiliki makna larangan. Kakung yang sedang duduk di meja membuat Karin terdorong untuk melarang dengan tuturan seperti di atas.

Berdasarkan paparan di atas, Karin lebih sering bertindak tutur direktif, terutama dalam bertindak tutur direktif melarang, meminta, dan menyuruh. Hal tersebut terjadi karena pada usia 4 tahun seperti Karin belum memerlukan tindak tutur menyarankan, menuntut, ataupun menasihati dalam komunikasinya bersama orang-orang di lingkungannya saat ini. Karin lebih sering bertindak tutur direktif melarang, menyuruh, dan meminta kepada mitra tutur. Karin sering bertindak tutur direktif melarang dan menyuruh disebabkan pula oleh seringnya mendengar dan melihat orang-orang di sekitarnya yang melarang dan menyuruh Karin untuk melakukan sesuatu sehingga tuturan tersebut digunakan juga oleh Karin.

\section{Tindak Tutur Komisif}

Tindak tutur komisif adalah tindak tutur yang mengikat penutur dengan sebuah tindakan-tindakan di masa depan, misalnya: berjanji, bersumpah, menawarkan, dan memanjatkan doa. Sesuai dengan penelitian yang telah dilakukan, hanya ditemukan satu jenis tindak tutur komisif yang diperoleh anak usia 4 tahun, yaitu menawarkan.

Menawarkan adalah mengucapkan tawaran dan penutur menawarkan sesuatu kepada mitra tutur (Ibrahim, 1993:36). Lebih 
lanjut, beliau juga mengatakan bahwa tuturan menawarkan dapat diikuti penerimaan atau penolakan, atau penjabaran lebih lanjut tentang kondisi-kondisi penawaran tersebut. Tindak tutur komisif menawarkan yang diperoleh anak usia 4 tahun tercermin dalam analisis dan uraian berikut.

Segmen Tutur Data (15)

Karin : "Dik, mau minta? Nih makan, Dik!"

Karin : "Ini, Dik, makan. Enak ini."

Konteks:

Tuturan terjadi ketika Karin makan makanan ringan dan Haidar makan coklat. Karin menginginkan coklat yang dimakan oleh mitra tutur. Dituturkan sambil menunjukkan makanan ringan yang dipegang oleh penutur kepada mitra tutur dengan nada rendah.

(TTKomMnwr:15)

Data (15) Dik, mau minta? Nih makan, Dik! merupakan tindak tutur komisif menawarkan. Hal tersebut tercermin dalam tuturan Karin, yaitu pada kalimat Dik, mau minta?. Pada tuturan tersebut, Karin bermaksud untuk menawarkan makanan yang dipegangnya kepada Haidar. Maksud tersebut dapat diketahui dari tuturan Karin yang menanyakan kepada Haidar apakah dia mau makanan ringan yang dipegang oleh Karin. Segmen tutur di atas menjelaskan bahwa Karin menginginkan coklat yang dipegang oleh Haidar karena coklat adalah makanan kesukaan Karin. Karin membawa makanan ringan yang juga disukai oleh Haidar. Karin menawarkan makanan ringan yang dipegangnya kepada Haidar. Sebelumnya, Haidar mengabaikan tawaran Karin. Kemudian, Karin menyuruh Haidar kembali agar mau memakan makanan ringan tersebut. Haidar mengambilnya dan Karin mengambil cokat yang dipegang oleh Haidar. Haidar yang sedang makan coklat, membuat Karin menginginkannya sehingga Karin menawarkan makanan ringan yang dipegangnya agar bisa bertukar dengan coklat milik Haidar.

Tindak tutur komisif berjanji, bersumpah, dan memanjatkan doa belum dikuasai oleh Karin. Beberapa kali Karin mampu menuturkan tindak tutur komisif berjanji. Akan tetapi, tuturan tersebut Karin ujarkan hanya karena paksaan dari mitra tutur, bukan merupakan keinginan atau dorongan dari diri pribadi anak.

\section{Tindak Tutur Ekspresif}

Tindak tutur ekspresif merupakan tindak tutur yang menunjukkan, mengekspresikan atau mengungkap sikap psikologis penutur kepada mitra tutur, misalnya ucapan terima kasih, memuji, mengucapkan selamat, meminta maaf, dan memaafkan. Sesuai dengan penelitian yang telah dilakukan, hanya ditemukan dua jenis tindak tutur ekspresif yang diperoleh anak usia 4 tahun, yaitu (1) berterima kasih dan (2) meminta maaf. 


\section{a. Tindak Tutur Ekspresif Berterima Kasih}

Tindak tutur ekspresif berterima kasih ditandai dengan tuturan dari penutur terhadap mitra tutur yang berisi sebuah ucapan terima kasih atas hal yang telah dilakukan oleh mitra tutur atau pihak yang dituju. Tindak tutur ekspresif berterima kasih yang diperoleh anak usia 4 tahun tercermin dalam analisis dan uraian berikut.

Segmen Tutur Data (16)

\begin{tabular}{|c|c|}
\hline \multicolumn{2}{|l|}{ Tante } \\
\hline \multicolumn{2}{|l|}{ Uti } \\
\hline Tante & :"Sana ambil, Kak." \\
\hline Uti & $\begin{array}{l}\text { : "Kene tak jipukne wis." } \\
\text { (Sini tak ambilkan sudah) }\end{array}$ \\
\hline Uti & $\begin{array}{l}\text { : "Nyoh, Kak, dipakek." (Sambil memberikan } \\
\text { helm Karin) }\end{array}$ \\
\hline & (Ini, Kak dipakai) \\
\hline Karin & : “Makasih, Ti.” (sambil memakai helm) \\
\hline \multicolumn{2}{|c|}{ Konteks: } \\
\hline \multicolumn{2}{|c|}{$\begin{array}{l}\text { Tuturan terjadi ketika Tante, Uti, dan Karin akan pergi } \\
\text { mengendarai motor. Helm milik Karin yang biasanya ada } \\
\text { di rumah depan, ternyata ada di rumah belakang. Tante } \\
\text { menyuruh Karin untuk mengambilnya di rumah belakang. } \\
\text { Kemudian, Uti yang bersedia untuk mengambilkannya. } \\
\text { Dituturkan dengan tulus dan memandang sambil } \\
\text { tersenyum kepada mitra tutur. }\end{array}$} \\
\hline
\end{tabular}

(TTEksTks:16)

Data (16) Makasih, Ti merupakan tindak tutur ekspresif berterima kasih. Pada tuturan tersebut, Karin bermaksud mengekspresikan perasaannya kepada mitra tutur (Uti) atas apa yang telah mitra tutur lakukan terhadap Karin. Maksud tersebut tercermin dalam penggunaan kata 'makasih' (terima kasih). Segmen tutur di atas menjelaskan bahwa Tante menyuruh Karin mengambil helm miliknya yang berada di rumah belakang. Lalu, Uti ingin mengambilkannya untuk Karin. Setelah diambil, helm tersebut Uti berikan kepada Karin. Karin mengucapkan terima kasih kepada Uti karena telah mengambilkan helm untuknya. Karin telah terbiasa menggunakan helm bila diajak pergi mengendarai motor. Dari kebiasaan tersebut, timbullah perasaan membutuhkan helm bila ingin pergi mengendarai motor. Oleh sebab itu, Karin merasa bersyukur dan senang karena Uti bersedia mengambilkan helm yang dibutuhkan oleh Karin.

b. Tindak Tutur Ekspresif Meminta Maaf

Tindak tutur meminta maaf digunakan oleh penutur untuk menyatakan perasaan bersalahnya atas tindakan yang dilakukan 
sebelumnya yang merupakan kesalahan terhadap mitra tuturnya. Tindak tutur ekspresif meminta maaf yang diperoleh anak usia 4 tahun tercermin dalam analisis dan uraian berikut.

Segmen Tutur Data (18)

Karin : "Tak injek, ya. Hayo tak injek."

Tante : "Aduh."

Karin : "Aduh maaf, ya." (dengan suara lirih sambil mengelus kaki Tante). Sudah.

Tante : "Ndak belum. Yang nyaring."

Karin : "Minta maaf, ya. Hehe."

Tante : "Jangan diulang, ya."

Karin : "Iya."

Konteks:

Tuturan terjadi ketika Tante sedang rebahan dan Karin berlari-lari di atas kasur. Karin bermaksud ingin bergurau bersama Tante dengan pura-pura menginjak kaki. Karin menginjak kaki tantenya hingga kaki tantenya terasa sakit. Dituturkan oleh penutur dengan nada lirih dan menyesal sambil mengelus kaki Tante yang tidak sengaja diinjaknya.

(TTEksMmf:18)

Data (18) Aduh maaf, ya merupakan tindak tutur ekspresif meminta maaf. Pada tuturan tersebut, Karin bermaksud mengekspresikan penyesalannya karena secara tidak sengaja menginjak kaki tantenya hingga terlalu keras. Maksud tersebut tercermin dalam tuturan Karin maaf, ya yang menandakan penyesalan Karin atas perbuatannya. Segmen tutur di atas menjelaskan bahwa Karin menginjak kaki Tante. Karin meminta maaf karena telah menginjak kaki tantenya. Karin meminta maaf dengan suara lirih kepada tantenya karena Karin terkadang masih merasa malu bila mengucapkan maaf kepada orang lain. Tante merasa Karin belum tulus meminta maaf dengan suara lirih sehingga Karin meminta maaf untuk kedua kalinya dengan suara lebih lantang kepada Tante. Kemudian, Tante mengingatkan Karin agar tidak mengulangi kesalahannya kepada tantenya atau bahkan kepada orang lain. Dengan mengulangi tuturan maaf tersebut, menandakan bahwa Karin benar-benar menyesal telah berbuat kesalahan.

Berdasarkan temuan dan analisis di atas, terdapat beberapa jenis tindak tutur ekspresif yang diperoleh Karin, yaitu tindak tutur ekspresif berterima kasih dan meminta maaf. Tindak tutur ekspresif berterima kasih lebih sering Karin gunakan dalam bertindak tutur untuk mengungkapkan rasa syukurnya karena telah menerima sesuatu dari mitra tutur. Akan tetapi, tindak tutur ekspresif meminta maaf masih sulit anak tuturkan karena rasa malu anak untuk mengakui kesalahan yang telah dilakukannya. 


\section{Tindak Tutur Deklaratif}

Tindak tutur deklaratif merupakan tindak tutur yang dilakukan oleh penutur dengan maksud menciptakan suatu hal yang baru atau sesuatu yang tidak sama dengan kenyataan ketika sebelum penutur mengucapkan tindak tutur deklaratif, misalnya memutuskan, membatalkan, memecat dan menghukum. Sesuai dengan penelitian yang telah dilakukan, hanya ditemukan satu jenis tindak tutur deklaratif, yaitu menghukum. Tindak tutur deklaratif menghukum adalah tuturan yang diujaran oleh penutur dengan maksud menjatuhkan hukuman kepada mitra tutur sebagai balasan atas kesalahan yang telah dilakukannya. Berikut analisis tindak tutur deklaratif menghukum yang diperoleh anak usia 4 tahun.

Segmen Tutur Data (19)

Bunda : "Mara, Kak, pakai katoknya, mara!"

(Ayo, Kak, pakai celananya, ayo!)

Karin : "Boh jangan, Bunda!"

Bunda : "Mara pakai!"

(Ayo pakai!)

Karin: "Nih, Dik, aku pakai ini nih, Dik. Dhina gak diajak kamu."

(Nih, Dik, aku pakai ini, Dik. Rasain gak diajak kamu.)

Konteks:

Tuturan terjadi ketika Karin diajak pergi oleh Uti dan Kakungnya. Karin bergegas mandi karena takut ditinggal pergi. Sebelum Karin mandi, Karin memberitahu adiknya kalau adiknya tidak akan diajak pergi bila tidak bergegas mandi. Setelah Karin mandi, Haidar masih bermain-main dan belum mandi. Kemudian, Haidar yang belum bersiapsiap tidak diajak pergi. Dituturkan dengan nada sinis.

(TTDekHkm:19)

Data (19) Dhina gak diajak kamu merupakan tindak tutur deklaratif menghukum. Pada tuturan tersebut, Karin bermaksud menghukum Haidar tidak boleh ikut pergi karena belum bersiap-siap. Maksud tersebut diketahui dari tuturan Karin Dhina gak diajak kamu yang dituturkan dengan nada sinis kepada mitra tutur (Haidar). Karin mengujarkan tuturan tersebut dengan bahasa Indonesia yang bercampur bahasa Madura. Kata dhina dalam bahasa Madura memiliki konotasi menghukum seseorang dengan cara mengejek. Oleh sebab itu, tuturan tersebut merupakan tindak tutur deklarasi menghukum. Karin yang diajak pergi oleh Uti beserta Kakungnya dan Haidar yang belum bersiap-siap untuk pergi, membuat Karin mengujarkan tuturan deklaratif menghukum. Segmen tutur di atas menjelaskan bahwa Bunda menyuruh Karin agar mengenakan celananya. Awalnya, Karin tidak mau memakainya, Bunda tetap memaksanya agar segera memakai celana. Karin menunjukkan celana yang dipakainya kepada Haidar. Kemudian, Karin menghukum Haidar dengan mengejeknya tidak boleh ikut pergi karena Haidar belum bersiap-siap. Pada akhirnya, Haidar memang tidak ikut pergi 
karena belum mandi.

\section{Pemerolehan Strategi Tindak Tutur Bahasa Indonesia Anak Usia 4 Tahun}

Strategi tindak tutur merupakan cara penyampaian yang digunakan penutur kepada mitra tutur untuk menyampaikan maksud tertentu. Berdasarkan data yang diperoleh, strategi tindak tutur bahasa Indonesia yang diperoleh anak usia 4 tahun mencakup: (1) strategi tindak tutur langsung harfiah, dan (2) strategi tindak tutur tak langsung harfiah.

\section{Strategi Tindak Tutur Langsung Harfiah}

Strategi tindak tutur langsung harfiah merupakan cara bertindak tutur yang maksudnya sama dengan bentuk tuturannya. Strategi tindak tutur langsung harfiah yang diperoleh anak usia 4 tahun terdapat pada data dan analisis berikut.

Segmen Tutur Data (20)

$$
\begin{array}{ll}
\text { Bunda } & \text { :"Sana ambil katok!" } \\
\text { Karin } & \text { :"Ayo Te, ambil, Te!" } \\
\text { Tante } & \text { :"Kasih apa Ante kalau ngambil?" } \\
\text { Karin } & \text { :"Kasih sepatu." }
\end{array}
$$

Konteks:

Tuturan terjadi ketika celana Karin basah setelah kencing di kamar mandi. Bunda menyuruh Karin agar mengganti celana dan mengambilnya di lemari tetapi Karin menolaknya. Tuturan diujarkan dengan nada tinggi oleh Karin.

$$
\text { (STLg:20) }
$$

Data (20) Ayo Te, ambil, Te! merupakan strategi tindak tutur langsung harfiah. Hal tersebut tercermin dalam tuturan Karin, yaitu ambil, Te!. Pada tuturan tersebut, Karin bermaksud menyuruh atau memerintah tantenya agar mengambilkan celana di lemari. Maksud tersebut diketahui dari penggunaan kata 'ambil' yang mewadahi makna isi suruhannya. Tuturan tersebut merupakan strategi tindak tutur langsung karena maksud yang diinginkan oleh Karin sama dengan bentuk tuturannya. Karin bermaksud agar mitra tutur mengambilkan celananya dengan menggunakan kata 'ambil' yang memiliki makna sama dengan maksud yang diinginkan oleh penutur.

Strategi tindak tutur langsung harfiah sangat sering anak tuturkan ketika bertindak tutur dengan keluarga dan teman-temannya. Hal tersebut menunjukkan bahwa anak telah memperoleh dan menguasai strategi tindak tutur langsung harfiah. Anak menggunakan strategi tindak tutur langsung harfiah karena anak lebih mudah untuk menggunakannya terhadap mitra tutur. Dengan menggunakan strategi tindak tutur langsung, mitra tutur akan lebih mudah memahami maksud anak ketika bertindak tutur. 


\section{Strategi Tindak Tutur Tak Langsung Harfiah}

Strategi tindak tutur tak langsung harfiah adalah cara bertindak tutur yang maksudnya berbeda dengan bentuk tuturannya. Artinya dalam tindak tutur tak langsung, penutur memiliki maksud yang berbeda dari wujud tuturan yang disampaikan. Strategi tindak tutur tak langsung harfiah yang diperoleh anak usia 4 tahun terdapat pada data dan analisis berikut.

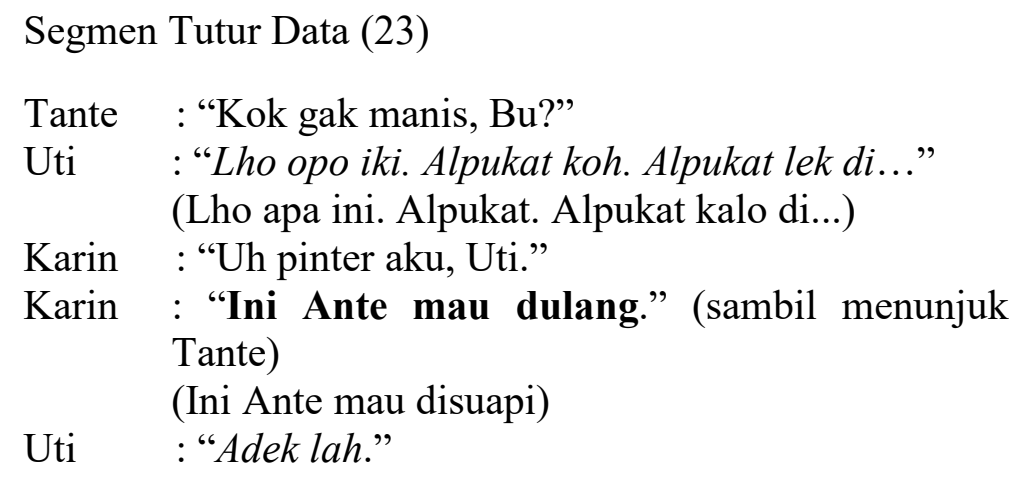
(Habis dah)

Konteks:

Tuturan terjadi ketika Uti, Tante, dan Karin menonton televisi bersama di ruang keluarga. Uti menyuapi Tante alpukat susu. Tidak lama alpukat sudah habis. Setelah beberapa saat, Karin tidak tahu kalau alpukat telah habis. Dituturkan dengan nada rendah sambil menunjukkan gelas alpukat dan menunjuk kepada Tante.

(STTakLg:23)

Data (23) Ini Ante mau dulang merupakan strategi tindak tutur tak langsung harfiah. Karin mengujarkan tuturan tersebut dengan maksud menyuruh Uti agar menyuapi Tante alpukat susu. Karin mengujarkan tuturan tersebut secara tidak langsung. Karin bermaksud menyuruh Uti dengan wujud tuturan yang maknanya berbeda dengan maksud sebenarnya, yaitu dengan cara memberitahu. Karin memberi tahu Uti bahwa Tante ingin disuapi alpukat, namun pada tuturan tersebut sebenarnya Karin menyuruh agar Uti menyuapi tantenya lagi, bukan hanya sekadar memberi tahu. Segmen tutur di atas menjelaskan bahwa Uti menyuapi Tante alpukat susu. Lalu, Tante menanyakan mengapa alpukat yang dibuat oleh Uti tidak manis. Kemudian, karena alpukat sudah habis, Uti tidak lagi menyuapi Tante. Karin menyuruh utinya agar menyuapi tantenya alpukat. Uti menanggapi bahwa alpukatnya sudah habis.

Strategi tindak tutur tak langsung harfiah yang diperoleh Karin sedang mengalami perkembangan dan mulai dikuasai oleh anak. Namun, anak tidak sering menggunakannya ketika bertindak tutur. Berdasarkan data-data yang telah ditemukan, anak dapat bertindak tutur secara tidak langsung ketika meminta sesuatu kepada mitra tutur yang anak tidak terlalu akrab dengannya atau kepada mitra tutur yang anak takuti. Oleh sebab itu, anak bertindak tutur secara tidak langsung agar apa yang dimaksudkan atau yang diinginkannya dapat terpenuhi. Selain itu, Karin bertindak tutur tak langsung karena Karin 
menganggap bahwa dengan strategi tersebut tuturan Karin akan terdengar lebih santun dan membuat mitra tutur merasa ingin mengikuti atau memenuhi keinginan Karin.

\section{Peran Lingkungan Terhadap Pemerolehan Tindak Tutur Bahasa Indonesia Anak Usia 4 Tahun}

Lingkungan adalah tempat untuk anak tumbuh dan berkembang. Melalui lingkungan, anak mendapatkan pengalaman dan memperoleh tindak tutur secara tidak disadari melalui orang-orang di sekitarnya, seperti keluarga, masyarakat, dan teman sebayanya bahkan objekobjek yang ada di sekitar anak juga berperan dalam pemerolehan tindak tutur anak. Lingkungan memiliki peran yang sangat penting dalam pemerolehan tindak tutur anak usia 4 tahun. Berikut ini paparan peran lingkungan terhadap pemerolehan tindak tutur bahasa Indonesia anak usia 4 tahun.

\section{Orang Tua dan Keluarga}

Orang tua dan keluarga merupakan orang-orang terdekat yang sering berkomunikasi bersama anak. Bersama orang tua, anak mampu dengan bebas menceritakan segala pengalamannya dan mengekspresikan perasaannya melalui tindak tutur. Orang tua dan keluarga yang menjadi orang terdekat anak, juga akan menjadi panutan serta orang-orang yang mudah untuk ditiru tuturannya oleh si anak. Anak usia 4 tahun akan dengan mudah menerima dan meniru tuturan orang-orang terdekatnya dengan sifat polosnya. Anak usia 4 tahun merasa bahwa orang tua dan keluarganya adalah orang-orang yang selalu benar dalam bertindak tutur dan sepatutnya menjadi orang-orang yang harus ditiru segala tindakan dan tuturannya. Selain itu, orang tua dan keluarga memiliki peran yang bermacam-macam bagi anak, misal sebagai mitra tutur yang aktif, sebagai teman, dan sebagai pendidik.

\section{a. Sebagai Mitra Tutur yang Aktif}

Anak usia 4 tahun merupakan masa-masa anak yang mulai aktif dalam bertindak tutur bersama orang-orang yang ada di sekitarnya. Terkadang anak banyak bertanya kepada orang-orang yang lebih dewasa tentang suatu hal yang baru bagi diri si anak. Dari tuturan anak yang semakin berkembang dan aktif, peran orang tua dan keluarga yang ada di sekitar anak menjadi sangat penting karena anak lebih sering bertindak tutur bersama orang-orang terdekatnya sehingga orang tua atau keluarga sering mendorong anak untuk bertindak tutur ketika sedang berkomunikasi.

Segmen Tutur Data (27)

$$
\begin{array}{ll}
\text { Bunda } & \begin{array}{l}
\text { :"Mara pakai katoknya." } \\
\text { (Ayo pakai celananya) }
\end{array} \\
\text { Karin } & : \text { "Uti, Uti nih, Uti." } \\
\text { Bunda } & : \text { "Mara, Kak pakai katoknya, mara." (sambil } \\
& \begin{array}{l}
\text { menyiapkan celana) } \\
\text { (Ayo, Kak pakai celananya, ayo) }
\end{array} \\
\text { Karin } \quad \text { :"Boh jangan, Bunda." }
\end{array}
$$


Bunda : "Mara pakai."

(Ayo pake)

Konteks:

Tuturan terjadi di kamar ketika Karin baru selesai mandi. Karin biasanya memakai baju sendiri tetapi pada saat itu Karin tidak segera memakai baju yang telah disiapkan oleh bundanya. Bunda menyuruh Karin untuk segera memakainya, namun Karin tetap tidak memakainya. Hingga pada akhirnya Bunda ingin memakaikan baju Karin agar segera dipakai. Karin menolaknya dan ingin memakainya sendiri.

(POTK:27)

Data (27) merupakan tindak tutur direktif melarang. Karin bertindak tutur direktif karena adanya pendorong dari Bunda. Bunda menyuruh Karin untuk memakai bajunya dan pada akhirnya ingin memakaikannya kepada Karin, membuat Karin merasa tidak nyaman dan ingin memakainya sendiri sehingga muncullah tindak tutur direktif tersebut. Hal tersebut menunjukkan bahwa Bunda selaku orang tua Karin berperan sebagai mitra tutur yang aktif bagi Karin karena Bunda memahami maksud larangan Karin dan membatalkan tindakannya untuk memakaikan baju Karin. Tuturan tersebut menjelaskan bahwa Bunda menyuruh Karin untuk segera memakai celana dan baju yang telah disediakan. Akan tetapi, Karin masih bermain-main dan tidak segera memakai bajunya. Hingga pada akhirnya Bunda memakaikan baju Karin agar cepat dipakai. Namun, Karin menolaknya karena ingin memakainya sendiri tanpa dibantu. Karin menolaknya dengan tuturan Boh jangan, Bunda.

\section{b. Sebagai Teman}

Anak usia 4 tahun selalu memandang orang tua dan keluarga adalah orang-orang yang terpercaya dan mampu mendengarkan segala cerita dan keluh kesahnya. Orang tua yang mengerti dan mampu memahami anak akan berusaha membuat anak nyaman untuk saling berkomunikasi dan saling bercerita tentang kegiatan-kegiatan selama di luar lingkungan keluarga, misal di sekolah atau ketika bermain dengan teman-temannya. Apabila anak telah nyaman bercerita dengan orang tu atau keluarga terdekatnya, maka anak telah menganggap bahwa keluarganya adalah teman untuk bercerita.

Segmen Tutur Data (29)

$$
\begin{array}{ll}
\text { Uti } & \text { : "Kamu kemarin ke mana, Kak naik mobil?" } \\
\text { Karin } & \text { :"Jalan-jalan sama Ayah." } \\
\text { Uti } & \text { : "Jalan-jalan ke mana?" } \\
\text { Karin } & \begin{array}{l}
\text { :"Mbak Ais ke kolam juga di sana tuh. Ada } \\
\text { hantunya." }
\end{array} \\
\text { Uti } & \begin{array}{l}
\text { : "Siah mak perak hantu malolo lek koe iki." } \\
\text { (Halah kok hantu terus kamu ini) }
\end{array} \\
\text { Karin } & \begin{array}{l}
\text { :"Boh hello kitty. Ye mus kimus kayak ini, } \\
\text { hihihih. Hih bejikna." }
\end{array}
\end{array}
$$


(Lho hello kitty. Ya mus kimus kayak ini, hihihih. Ih jijik)

Uti : "Takut aku."

Karin : "Ada temen-temennya di sana."

Uti : "Banyak?"

Karin :"Banyak. Dak banyak teman-temannya."

Konteks:

Tuturan terjadi di mobil ketika Karin bersama Uti, Kakung, dan Tante. Pada hari sebelumnya, Karin pergi bersama ayah dan bundanya naik mobil. Uti menanyakan ke mana Karin pergi pada hari itu bersama ayah dan bundanya. Lalu, Karin menceritakan kegiatannya pada saat itu.

(POTK:29)

Data (29) menunjukkan bahwa Uti selaku keluarga yang dekat dengan Karin juga menjadi teman bercerita bagi Karin. Hal tersebut dapat diketahui dari segmen tutur di atas. Segmen tutur tersebut menjelaskan bahwa Uti menanyakan kegiatannya ketika naik mobil bersama ayah dan bundanya. Lalu, Karin melaporkan kegiatannya bersama Ayah, Bunda, dan Mbak Ais ketika pergi bersama. Karin pergi ke kolam renang bersama Mbak Ais dan di kolam renang Karin melihat badut hello kitty yang mirip hantu menurut Karin. Karin dengan semangatnya menceritakan dan melaporkan kegiatankegiatannya pada saat itu kepada Uti. Pertanyaan Uti yang menanyakan pergi ke mana, mendorong Karin untuk melaporkan dan menceritakan kegiatannya dan apa saja yang dilihatnya di tempat tersebut. Karin dengan nyamannya dan semangatnya menceritakan hal tersebut karena Karin merasa bahwa Uti adalah orang yang baik sebagai pendengar. Setiap kali Karin pergi tanpa Uti, Uti selalu menanyakan kegiatan Karin sehingga hal tersebut menjadi terbiasa bagi Karin untuk menceritakannya kepada Uti.

c. Sebagai Pendidik

Orang tua dan keluarga merupakan orang-orang yang menjadi teladan bagi anak usia 4 tahun. Orang tua dan keluarga terdekat akan sangat mudah untuk memberikan berbagai contoh tindak tutur ataupun mendidik anak melalui tuturan. Melalui tuturan yang keluarga contohkan, maka anak akan terdorong pula untuk melakukan tindak tutur tersebut.

Segmen Tutur Data (30)

Karin : "Huиu benyak lah itu kuburannya. Huu takut aku. Huu hantu, Te."

Tante : "Gak ada hantu. Gak boleh takut sama hantu. Takut itu sama?"

Karin : "Hantu."

Tante : "Boh. Takut hanya boleh sama satu. Kepada siapa?" 
Karin : "Kuburan."

Tante : "Lho hahaha. Takut hanya kepada All...?"

Karin : "...Llah."

Tante : "Jadi takut hanya kepada? Siapa?"

Karin : "Hantu."

Tante : "Lho. Takut hanya kepada All..?"

Karin : "...Llah."

Tante : "Gak boleh takut ke?"

Karin : "Allah."

Tante : "Lho. Gak boleh takut ke?"

Karin : "Hantu."

Tante : "Hanya takut kepada?"

Karin : "Allah."

Tante : "Iya. maasyaAllah. Hantu itu ada apa nggak?"

Karin : "Gak ada."

Tante : "Jadi gak boleh takut ke?"

Karin : "Hantu."

Tante : "Iya bagus, maasyaAllah."

Karin: "Itu bukan itu. Hantu itu tadek. Terus itu apa itu?"

Tante : "Bukan, itu gambar. Gambarnya orang dahulu."

Konteks:

Tuturan terjadi ketika Karin bersama Tante menonton TV yang bercerita tentang para pahlawan dan makammakamnya. Pada awalnya, Karin menyatakan bahwa dirinya takut dengan hantu. Kemudian, Tante memberi tahu kepada Karin bahwa tidak boleh takut pada hantu dan hanya takut kepada Allah. Lalu, Karin menyatakan kembali bahwa hantu itu tidak ada dan tidak boleh takut kepada hantu.

(POTK:30)

Data (30) Itu bukan itu. Hantu itu tadek merupakan tindak tutur yang menunjukkan bahwa keluarga sebagai pendidik bagi anak. Tuturan tersebut diujarkan oleh Karin. Karin mampu bertindak tutur seperti pada tuturan di atas karena adanya edukasi dari Tante sebelumnya yang mengajarkan bahwa hantu itu tidak ada dan tidak boleh takut kepada hantu. Hal tersebut menunjukkan bahwa Tante selaku keluarga Karin berperan sebagai pendidik atau edukator bagi Karin hingga Karin mampu bertindak tutur asertif seperti segmen tutur di atas. Segmen tutur di atas menunjukkan bahwa Karin menyatakan ketakutannya terhadap hantu. Namun, Tante meluruskan dan memberi tahu Karin agar tidak takut terhadap hantu dan hanya boleh takut kepada Allah. Tante secara sabar mengajarkan Karin sampai benar-benar paham bahwa manusia tidak boleh takut terhadap hantu dan hanya boleh takut kepada Allah. Setelah diberitahu berulang kali oleh Tante, Karin mulai paham dan menyatakan dirinya tidak takut dengan hantu dan menyatakan bahwa hantu itu tidak ada.

Berdasarkan data dan analisis di atas, dapat diketahui bahwa orang tua dan keluarga berperan dalam pemerolehan tindak tutur 
Karin. Karin lebih sering bertindak tutur bersama orang tua dan keluarganya daripada bersama orang lain. Hal tersebut disebabkan oleh peran orang tua dan keluarga sebagai mitra tutur yang aktif, sebagai teman, dan sebagai edukator bagi Karin. Melalui peran-peran tersebut, membuat Karin lebih terbuka untuk berkomunikasi dan terdorong untuk melakukan berbagai tindak tutur bersama orang tua dan keluarganya. Selain itu, hampir semua waktu yang dimiliki oleh Karin dihabiskan bersama orang tua dan keluarga sehingga banyak pula tuturan-tuturan yang Karin dengar dari keluarga.

\section{Teman Sebaya dan Masyarakat}

Anak usia 4 tahun mulai berinteraksi bersama orang-orang di luar keluarganya, yaitu di sekolah maupun di lingkungan tempat tinggal anak. Interaksi anak dengan teman sebayanya dan masyarakat di lingkungannya memiliki peran khusus terhadap perkembangan pragmatik anak sehingga kemampuan anak dalam bertindak tutur akan semakin kompleks. Teman sebaya dan masyarakat berperan sebagai model dalam bertindak tutur bagi anak usia 4 tahun. Banyak tindak tutur yang diperoleh anak usia 4 tahun dari teman sebaya dan masyarakat. Tuturan tersebut biasanya ditiru oleh anak ketika sedang bermain atau bercakap-cakap setiap harinya sehingga teman sebaya dan masyarakat berperan sebagai model bagi anak usia 4 tahun. Banyak tuturan yang Karin peroleh dari teman-temannya di sekolah maupun di lingkungan tempat tinggalnya. Misalnya pada segmen tutur berikut.

Segmen Tutur Data (31)

Rana : "Jangan marah-marah masih kecil. Masuk neraka kamu."

Aka : "Nanti itu bisa kering sendiri ya."

Rana : "He'em. Bisa kering sendiri lho."

Aka : "Nisa bajunya becca wah. Bisa kering sendiri." (Nisa bajunya basah tuh. Bisa kering sendiri)

Rana : "Iya bisa kering sendiri. Ndak boleh gitu kamu sama temen dosa."

Aka : "Sak an eh."

(Geser dong)

Karin : "Jangan! Kamu jangan marah-marah kamu! Nanti dosa. Awas, Ka!"

Rana : "Temennya ndak boleh marah juga, nanti kalo temennya marah, marah juga. Coba dah.”

Konteks :Tuturan terjadi di sekolah ketika Karin bersama teman-temannya bermain pelosotan. Aka menyuruh penutur untuk bergeser dari tempat berdirinya dengan nada tinggi karena Aka ingin berdiri di sampingnya. Dituturkan dengan nada rendah dan tegas.

(PTSM:31)

Pada segmen tutur di atas, Karin melarang seorang temannya agar tidak marah-marah. Tuturan tersebut ada pada kalimat Jangan! Kamu 
jangan marah-marah kamu! Nanti dosa. Awas, Ka! Tuturan tersebut termasuk tindak tutur direktif melarang. Karin bertindak tutur direktif melarang karena terdorong oleh tuturan dari mitra tutur yang pada saat itu berbicara kepada Karin seperti orang marah-marah atau dengan nada tinggi. Karin menganggap Aka sebagai teman dekatnya sehingga Karin berani untuk melarang Aka agar tidak marah-marah ketika berbicara. Apabila Aka bukan teman dekat Karin, maka Karin tidak akan berani untuk bertindak tutur melarang seperti pada segmen tutur di atas.

Selain itu, Karin mampu menuturkan kalimat tersebut karena menirukan temannya, yaitu Rana yang sebelumnya juga menuturkan kalimat serupa. Salah satu teman Karin di sekolah, sering bertindak tutur melarang teman-temannya agar tidak marah-marah karena itu perbuatan dosa. Karin sering mendengar tuturan hal semacam itu dari teman-temannya sehingga Karin meniru tindak tutur serupa yang ditujukan kepada teman-temannya juga.

Tuturan yang diujarkan oleh Karin banyak yang diperoleh melalui proses meniru guru atau pun teman sebayanya. Karin sering menirukan guru-gurunya ketika di sekolah. Misalnya seperti memerintah atau menyuruh. Guru Karin sering memerintah anak didik yang lain agar berhati-hati ketika bermain dan melarang siswa lain agar tidak bermain di tempat-tempat yang berbahaya. Dari tuturan yang sering dituturkan oleh gurunya, Karin mulai meniru gurunya dengan melarang teman-temannya agar tidak bermain di tempat yang tinggi.

\section{Objek-objek di Sekitar Anak}

Lingkungan ketiga yang berperan terhadap pemerolehan tindak tutur anak usia 4 tahun adalah objek-objek di sekitar anak. Anak pada usia 4 tahun, mampu mempertautkan antara objek dengan fungsifungsinya. Objek-objek yang ada di sekitar anak membantu anak dalam bertindak tutur. Karin telah mampu memahami fungsi-fungsi beberapa objek yang sering dia temui di lingkungannya, yaitu di rumah maupun di sekolah. Berikut uraiannya.

Segmen Tutur Data (33)

\section{Karin: "Hei, jangan naik tinggi-tinggi kamu! Nanti jatuh kamu."}

Nisa : "Sini, Mbak Karin naik."

Karin: "Ndak, ndak mau aku. Nanti jatuh, sakit aku kaki pas."

Konteks:

Tuturan terjadi ketika Nisa bermain besi panjat di sekolah. Nisa mengajak Karin untuk ikut naik tetapi Karin 
menolaknya. Dituturkan dengan nada tinggi.

(POSA:33)

Segmen tutur di atas menjelaskan bahwa Karin melarang Nisa agar tidak terlalu tinggi memanjat besi karena Karin khawatir Nisa jatuh. Kemudian, Nisa mengajak Karin untuk memanjat juga. Akan tetapi, Karin enggan untuk naik besi panjat karena beberapa hari sebelumnya, Karin pernah jatuh dari besi panjat tersebut. Hal tersebut membuat Karin trauma sehingga tidak mau lagi bermain panjat besi. Ketika Karin melihat Nisa memanjat besi tersebut, Karin secara langsung melarang Nisa agar tidak terlalu tinggi ketika memanjat dengan tuturan Hey jangan naik tinggi-tinggi kamu. Nanti jatuh kamu. Karin dengan spontan mengujarkan larangan tersebut karena Karin mengaitkan pemahamannya terhadap objek tersebut (besi panjat) dengan pengalamannya ketika terjatuh dari benda tersebut. Dengan pemahaman tersebut, Karin terdorong untuk bertindak tutur direktif melarang ketika melihat temannya memanjat besi tersebut.

Berdasarkan paparan di atas, Karin telah menguasai banyak tuturan karena adanya peran dari objek-objek di sekitarnya. Objekobjek atau benda-benda tersebut berperan sebagai pendorong Karin dalam bertindak tutur. Pemahaman Karin terhadap fungsi bendabenda yang ada di sekitarnya membuat Karin mampu untuk bertindak tutur. Karin mempelajari fungsi objek-objek yang ada di sekitarnya untuk digunakan dalam bertindak tutur. Dengan adanya pemahaman terhadap fungsi objek-objek tersebut, tindak tutur yang diujarkan oleh Karin akan lebih kompleks karena Karin mampu mempertautkan objek-objek tersebut dengan kejadian-kejadian di sekitarnya melalui tindak tutur.

\section{SIMPULAN}

Berdasarkan hasil penelitian dan pembahasan mengenai Pemerolehan Tindak Tutur Bahasa Indonesia Anak Usia 4 Tahun, maka dapat disimpulkan beberapa hal sebagai berikut. Pertama, terdapat beberapa jenis tindak tutur bahasa Indonesia yang diperoleh anak usia 4 tahun, yaitu (1) tindak tutur asertif. Ditemukan beberapa jenis tindak tutur asertif yang diperoleh Karin yang berusia 4 tahun, yaitu tindak tutur asertif menyatakan, melaporkan, dan menunjukkan. Tindak tutur asertif mengeluh, mengemukakan pendapat, dan mengusulkan belum dikuasai oleh Karin. Berdasarkan data yang ditemukan, pemerolehan tindak tutur asertif yang terjadi pada Karin disebabkan oleh kemauan yang besar dari diri anak untuk bercerita, memberitahukan segala sesuatu yang baru bagi si anak kepada mitra tutur, atau pun memamerkan hal-hal yang membuat anak merasa bangga diri kepada mitra tutur. (2) Tindak tutur direktif. Dalam penelitian ini ditemukan tiga jenis tindak tutur direktif yang diperoleh Karin, yaitu meminta, memerintah atau menyuruh, dan melarang. Karin lebih sering bertindak tutur melarang, menyuruh, dan meminta kepada mitra tutur. Hal tersebut terjadi karena pada usia 4 tahun seperti Karin belum memerlukan tindak tutur menyarankan, menuntut, ataupun menasihati dalam komunikasinya. (3) Tindak tutur komisif. 
Pada tindak tutur komisif hanya ditemukan satu jenis yang dikuasai oleh Karin, yakni tindak tutur komisif menawarkan. Tindak tutur komisif menawarkan diujarkan oleh Karin ketika Karin menawarkan sesuatu, seperti makanan kepada mitra tutur. (4) Tindak tutur ekspresif. Terdapat beberapa jenis tindak tutur ekspresif yang diperoleh Karin, yaitu tindak tutur ekspresif berterima kasih dan tindak tutur ekspresif meminta maaf. Tindak tutur ekspresif berterima kasih lebih sering Karin gunakan dalam bertindak tutur untuk mengungkapkan rasa syukurnya karena telah menerima sesuatu dari mitra tutur, sedangkan tindak tutur ekspresif meminta maaf Karin gunakan sebagai tanda bahwa Karin menyesali kesalahannya terhadap mitra tutur. (5) Tindak tutur deklaratif. Dalam penelitian ini hanya ditemukan satu jenis tindak tutur deklaratif, yaitu berupa tindak tutur deklaratif menghukum.

Kedua, strategi bertutur adalah cara penyampaian yang dilakukan oleh penutur untuk mengekspresikan maksud yang dikehendaki. Strategi tindak tutur bahasa Indonesia yang diperoleh anak usia 4 tahun dibagi menjadi dua, yaitu (1) strategi tindak tutur langsung harfiah. Strategi ini sangat sering Karin tuturkan ketika bertindak tutur dengan keluarga dan teman-temannya. Anak menggunakan strategi tindak tutur langsung harfiah karena anak lebih mudah untuk menggunakannya terhadap mitra tutur. (2) Tindak tutur tidak langsung harfiah. Pada penelitian ini, Karin dapat bertindak tutur secara tidak langsung ketika meminta sesuatu kepada mitra tutur yang Karin tidak terlalu akrab dengannya atau kepada mitra tutur yang Karin takuti.

Ketiga, pemerolehan tindak tutur bahasa Indonesia anak usia 4 tahun disebabkan oleh peran lingkungan yang ada di sekitar anak. Peran tersebut dibagi menjadi tiga, yaitu (1) orang tua dan keluarga. Anak menghabiskan banyak waktu bersama orang tua dan keluarga sehingga orang tua dan keluarga menjadi mitra tutur yang aktif bagi si anak, sebagai teman yang selalu mendengarkan segala tuturan anak, dan sebagai pendidik bagi anak karena orang tua memberikan banyak pelajaran kepada anak di awal perkembangannya. (2) Teman sebaya dan masyarakat. Anak usia 4 tahun banyak meniru tuturan-tuturan yang didengar dari masyarakat dan teman-teman sebayanya. (3) Objek-objek di sekitar anak. Anak mampu untuk bertindak tutur disebabkan adanya objek-objek yang mendorongnya untuk mengujarkan sebuah tuturan. Anak mempelajari fungsi objek-objekdi sekitarnya untuk digunakan bertindak tutur dengan orang-orang di sekitarnya.

\section{DAFTAR PUSTAKA}

Arikunto, Suharsimi. 2002. Prosedur Penelitian Suatu Pendekatan Praktek. Jakara: Rineka Cipta.

Asih, Mutiara Karna. 2017. Pemerolehan Kompetensi Pragmatik Bagi Anak Berbahasa Ibu Bahasa Inggris (Sebuah Kajian Psikopragmatik Studi Kasus pada Anak Video Blogger Usia
2-4 Tahun). Tesis. Semarang: Universitas Diponegoro.

Austin, J.L.1995. How To Do Things With Words. New York: Oxford University Press.

Candrasari, L. A. 2014. Pemerolehan Bahasa Anak Usia 3-4 Tahun di Desa Gombong Kecamatan Belik Kabupaten Pemalang. Naskah 
Publikasi. Surakarta: Universitas

Muhammadiyah Surakarta.

Chaer, Abdul. 2015. Psikolinguistik:

Kajian Teoritik, edisi Revisi. Jakarta:

Rineka Cipta.

Dardjowidjojo, Soenjono. 2000. Echa:

Kisah Pemerolehan Bahasa Anak

Indonesia. Jakarta: Gramedia.

Ibrahim, Abdul Syukur. 1993. Kajian

Tindak Tutur. Surabaya: Usaha Nasional.

Leech, Geoffrey. 1983. The Principles of

Pragmatics. Longman Group Limited.

Terjemahan oleh Dr. M.D.D Oka,

M.A. 2015. Prinsip-Prinsip

Pragmatik. Jakarta: Universitas

Indonesia.

Milles, Matthew. B dan A. Michael Huberman. 1992. Analisis Data Kualitatif. Buku Sumber Tentang Metode-metode Baru. Jakarta: Universitas Indonesia (UIPress).

Moleong, Lexy J. 2009. Metodologi Penelitian Kualitatif. Bandung: PT. Remaja Rosdakarya.

Parera, Jos Daniel. 1987. Teori Semantik. Jakarta: Erlangga.

Prayitno, Joko Harun. 2011. Kesantunan Sosiopragmatik. Surakarta:

Muhammadiyah University Press.

Santrock, W. J. (2007). Perkembangan Anak. Jakarta: Erlangga.

Sukmadinata, Nana Syaodih. 2012. Metode Penelitian Pendidikan. Bandung: PT Remaja Rosdakarya.

Tarigan, Henry Guntur. 1990. Pengajaran Pragmatik. Bandung: Angkasa.

Yusuf, Syamsu. 2004. Psikologi Perkembangan Anak dan Remaja. Bandung: Remaja Rosdakarya. 